\title{
Unit Cost Analysis in Higher Education
}

\author{
Asep Kurniawan, Tjutju Yuniarsih, Sumarto \\ Faculty of Economic and Business Education \\ Universitas Pendidikan Indonesia \\ kurniawan.asep@gmail.com
}

\begin{abstract}
This study analyzed the calculation of unit costs in higher education. The focus of this research is on how the needs analysis process in college, and how the calculation of unit costs in higher education. The method used was a case study with a qualitative approach. The object of this study in the domestic higher education incorporated the ITB, IPB, and UPI. The resulting research findings that each college has a standard component in the calculation of the cost of formulating educational units will be determined based on the needs of each business unit in a university. Calculation of unit cost of education was using activity-based costing method. Calculation of unit cost of education does not include indirect costs is the cost of student life, and the opportunity cost. This study concluded that the cost of educational units is calculated by the college is still larger than the calculation made by the government. It is due to that the government has not been fully able to meet the shortage of funds used by the college. Further research is expected to cost calculations take into account the educational unit indirect costs of living cost and opportunity cost.
\end{abstract}

Keywords: unit cost, activity based costing, higher education.

\section{INTRODUCTION}

Financing of education not only includes the search of resources and the allocation of education funds appropriately. Educational institutions should also consider how much the unit cost necessary for the implementation of quality learning process. The process of calculating the unit cost of education will depend on the method used by institutions / agencies concerned. In general, the number of unit cost of education obtained of the total expenditure divided by number of students, as proposed by Bowen (1981).

Basically, many factors must be taken into account in determining the unit cost of education, but in general can be calculated by dividing the total expenditure by the number of college students. The method of determining the unit cost of education could also affect accurate and whether or not the number of the unit cost of education. This is supported by the explanation that "some research suggests that the cost per student can be influenced by several factors, including the ratio of faculty students, the average salary of professors, type of college (public vs. private), and geographical location" (Paulsen, 2001, p. 133). Thus, some of these factors becomes a matter that should be taken into account in determining the amount of the unit cost of education.
But in its implementation, the calculation of the unit cost of education is still limited by the budget limit that is determined by the policy of an institution. Ideally, the determination of the cost of the education unit refers to a certain standard and based on the analysis of costs required by the students for completing his studies at the college. Research conducted by Sumarto and Nana Fattah (2013) shows the unit costs of education in some university campuses by calculation using the $\mathrm{ABC}$ method, there is a considerable margin, especially in LPTK, the biggest margin reached $330.87 \%$ for cluster technology, while the smallest difference in social sciences cluster by $123.74 \%$. This shows that there are differences between the calculations of what is conveyed by the ministry with the real situation. On this basis the authors are interested in further research on the management of the unit cost of education.

\section{UNIT COST}

Many factors determine the cost of this education unit, before getting on the unit costs of education, will be presented in advance understanding of the cost of higher education. Bowen (1981, pp. 1-2) argues that: The cost of colleges and universities are usually money payment to acquire the resources needed to operate and the institutions. They include cash outlays for the wages and Salaries of personnel, the purchase of good services, student financial aid, and the acquisition or use of plant and equipment. Simply put, the unit cost of education can be calculated by dividing the total expenditure by the number of all students, as proposed by Bowen (1981, p. 4) that, "Traditionally, what passed as cost per unit was computed simply by adding up the total institutional expenditures for all purposes and dividing by the number of student. The result was called "cost per student". For accuracy and precision in calculating the cost of taken steps to make the cost categories in advance. By classifying costs, there are cost elements such as raw materials and auxiliary materials, the use of human labor, the abolition of the means of production durable, ground services, and other third party services. Idochi Anwar (2004, p. 144) classifies costs as follows:

1. Direct costs, i.e. costs that are directly in the production process into a unit of output. Such as: raw materials and auxiliary materials, as well as direct labor

2. Indirect costs, i.e. costs that are not directly in the production process so that it does not look directly in units of output, and is often called overhead costs, such as indirect materials, indirect labor, rent, payroll 
tax, property tax, removal machine, repair, maintenance of insurance, and others. This is in accordance with the opinion of Roe L. Johns, et al (1983, p. 45), that: Education has both private and social cost, the which may be both direct and indirect, direct costs are incurred for tuition, fees, books, room and board. In a public school, the majority of Reviews These costs are subsumed by the public treasury and Tus Become social costs. Indirect costs of education are embodied in the earnings forgone bay roommates are all persons of working age, but forgone earnings are Also a cost to society is a reduction in the total productivity of the nation. Direct costs consist of costs incurred for the purposes of the implementation of the teaching and learning activities of students. Most of the cost comes directly from the school system itself such as SPP, and the contribution of parents for education or issued by the students to buy supplies in implementing the education process, such as the cost of books, equipment and pocket money. Whereas the indirect costs of lost profit in the form of lost opportunities and sacrificed by students while studying. Cohn (1979, p. 62) states that Direct costs have received by far the bulk of attention, perhaps Because he consequences of such costs are Directly and strongly felt by the tax payer-and, of course, Because statistics on direct school outlays are readily available (or estimable), where as indirect cost must be imputed. The majority of direct costs are incurred by the school systems themselves.

Further Cohn (1976, p. 62) describes the cost of education can be categorized as follows

1. Direct costs (direct costs), which are expenses incurred directly to finance the implementation of teaching, research and community service, such as teacher salaries, employee non-educative, textbooks and other supplies materials. This affects the educational outcomes of value-sacrifice for the implementation of these activities.

2. Indirect costs (indirect costs), which includes the loss of income because learners are following education. It could also be the lost profits (earnings forgone) in the form of lost opportunity costs (opportunity cost) are sacrificed by students while studying. The calculation of the cost of education will be determined by the elements that are based also on the calculation of the real costs according to the activities by type and volume. In the concept of the financing of education, there are two important things that need to be studied and analyzed, namely the cost of education as a whole and unit cost per learner. Unit costs at the college level is the cost of education is sourced either from the government, parents and the community to support the delivery of education in a school year. This was confirmed also by Howard R. Bowen (1981, p. 1)

Argued that "Cost Appear usually in the form of expenditures of money. Similarly, costs of colleges and universities are usually money payments to acquire the resources needed to operate and the institutions ". The unit cost per learner is a measure that describes how much money is allocated to educational institutions effectively for the benefit of students in the study. This was emphasized by Howard R. Bowen (1981, p. 4), which "What passed as cost per unit was adding up the total institutional expenditure for all purposes and dividing by the number of students". By analyzing the cost of the unit, allowing to determines the efficiency in the use of resources in higher education, the benefits of educational investment, and equity of public spending. In terms of real costs in an educational, Bowen (1981) found .The real cost, however, lie beneath the money payments. The products of the outcomes of higher education are Obtained through the source of scarce resources. The real cost of higher education, then, Consist of benefits that might have been the Tirrenus from Reviews These resources, but were Sacrificed, Because Reviews These resources were committed to higher education. (P. 2) Further Bowen (1981, p. 3) explains the overall costs that All that needed is to add up all expenditures-making sure to include only the costs that are properly allocated to the year in question. But, even when adjusted for changes in the value of the dollar, this total is not meaningful for comparisons over time Among institutions UNLESS it is related to the number of units of service rendered Analysis of college financial efficiency in the utilization of financial resources and the results can be done by analyzing the cost per student. The unit cost per student is the average cost per student is calculated from the total expenditure divided by all students in higher education within a certain time. By knowing the size of the unit cost per student is useful to assess various policy alternatives in an effort to improve the education quality. To calculate the cost per student, Bowen (1981, p. 12) states that: Some experts argue that costs can be defined on purpose and a different perspective. The definition of the macro, the cost must consider society as a whole and include all costs incurred for the college to produce all outputs and outcomes, including institutional spending, the individual costs, opportunity costs, and other public spending. On the other hand, in micro, cost or expense is focused on the activities undertaken by the organization or higher education institution. This perspective does not include opportunity costs, and expenses for college students. In the perspective of the individual, cost or expense is all expenditure incurred by the students to obtain a college education. The financial data used to calculate the cost of college is usually obtained from the financial records of an institution. Bowen (in Paulsen and John.C, 2001, p. 87) suggests that the most important factors that may explain the differences in the unit cost of education from various universities is a measure of the academic program (S1, S2, and S3), the type of program academic, as well as the type of graduates. The increase in the income level of employees is also a determinant factor in the financing of higher education. The institutional efforts to improve service quality and output (by lowering the student faculty ratio, increase materials, facilities and equipment) seem to be driving up costs. Moreover, in determining the unit cost of education need to consider the calculation method to be used. The method used in calculating the unit cost of education is a method of 
Activity-Based Costing. Blocher, Chen and Lin (2000) argues that Activity-Based Costing approach is the determination of product cost charge to products or services based on resource consumption caused by the activity. The rationale for determining the cost of this approach is that the company's products or services performed by the activity and activities required the use of resources that causes the cost. Along it, Atkinson, et al. (2001) suggested that the "Activity-Based Costing (ABC) as an activity-based cost accounting system that connects the resources used by organizations with products or services produced or received by customers" (p. 56). Later, Maher, et al (1996) suggested that the ActivityBased Costing is "a method for calculating the cost of the product or service in accordance with the cost of activities that are used to produce goods or services" (p. 71).

\section{RESEARCH METHODOLOGY}

The method used in this study is the case study method with qualitative approach. In this dissertation research, the research method used was a case study (case study research), which is trying to learn a phenomenon in the case and in a real context. The aim is to analyze in depth the whole phenomenon that is the cycle of the focus of the investigation in order to establish a broader generalization. In using this qualitative approach, the researchers used the logic of inductive thinking that departs from the rules that are specific to the general. A short description of the actual implementation of this method departs and is identical to the schools of post-positivistic. It was based on the fact that qualitative methods in social research departs from the paradigm that every aspect of social reality viewed holistically as a natural unity which need to be interpreted in depth, especially social reality is understood as a pluralistic reality. On this basis then qualitative methods more emphasis on the search for meaning behind empirical of social reality so that a deep understanding of social reality are all concerned in this method. The object of this study was conducted in 3 Universities, the Institut Teknologi Bandung (ITB), Universitas Pendidikan Indonesia (UPI), and Institut Pertanian Bogor (IPB). Three State Universities which have the same characteristics, which has a study program ranging from Diploma Program, $\mathrm{S} 1, \mathrm{~S} 2$, and S3, as well as get funding from the government.

\section{FINDING}

Each college has its own distinctive scientific, Bandung Institute of Technology has offered 3 scientific groups, while the University of Indonesia has a specific scientific groups in the field of education. However, in calculating the unit cost of education, particularly BKT and UKT have a base or reference the same provision is based on the provisions of the Government, in this case the Ministry of Research, Technology and Higher Education although the level of the approach and calculation of components ideally matched to provisions are at each college. In addition, the college is only counting the direct costs and indirect costs required during the process of education in college, not counting the personal cost incurred by each student outside of the educational process (lectures). In calculating the unit cost of education a course of study based on the Implementation Cost of Education (BPP) which components it is Tuition Single (UKT), each student in a course has a value UKT different according to the filing stipulated in SK Rector. In calculating the unit cost of university education based on the needs analysis activities that will be done in the level of solids, the Directorate, faculty and study program. Thus each unit can be involved directly or indirectly in the budget formulation process to be set in order to give birth to the unit cost of education required (activity based costing). In calculating the unit cost that is ideal for each university has the same provision calculation formula for the direct and indirect costs in supporting the lecture, whereas for the calculation of the indirect costs of a personal nature not included in the calculation of unit cost components of the study program. In calculating the unit cost of education a course of study was based on various aspects such as the number of students, analysis of the activities to be carried out, the income of parents, as well as per-subject requirement is needed. Each college has a unique scholarship offered to address the needs of society. In this case the ITB has offered typical science is science, engineering and humanities, while the UPI has a distinctive knowledge in the field of education so that science has to offer is in the field of education or non-education. Through the analysis of the unit cost can make it easier to determine the efficiency in the use of resources in higher education, benefits and education investment as well as the estimated expenditure required. In this case, based on the findings of the field coming from three universities legal status (PTN-BH) had findings that are basically in the needs analysis and calculation of the unit cost of education, especially in BKT and UKT have a base or reference provisions based on government provision.

\section{CONCLUSION}

Based on the findings empirically, it can be concluded that basically every college has a standard calculation components in the formulation unit cost of education will be determined based on the needs of the work unit in higher education, and it also refers to the government decree on the provision BKT and UKT colleges. Thus, in conducting a need analysis and calculation of the cost of college education units are based on the program and need to be held through activities based costing method.

\section{REFERENCES}

[1] Atkinson, Rajiv D. Banker, Robert S. Kaplan, Mark Young. (2001) Management accounting (edisi ketiga). New Jersey: Prentice Hall, Inc.

[2] Bassey, M. (1999). Case study research in educational settings. Philadelphia: Open University Press.

[3] Bowen, H. R. (1980). The cost of higher education, how much do colleges and universities spend per student and how much should they spend?. San Francisco: Jossey-Bass Publisher.

[4] Bowen, H. R. (1981). The cost of higher education. Washington : Jossey-Bass Publisher.

[5] Blaug, Mark. (1976). Economics of education. Universitas Michigan, U.S : The Penguin Press. 
[7] Blocher, Chin dan Lin. (2000). Manajemen biaya. Jakarta : Salemba Empat

[8] Blocher, et.al., (2005). Cost management: a strategic emphasis, New Yok: McGraw-Hill Co., Inc.

[9] Cohn, Elchanan. (1979). Economics of education (revision edition). Printed in United States of America

[10] Coombs, Philip H., \& J. Hallak. (1972). Managing Educational Cost, London: Oxford University Press

[11] Fattah, Nanang. (2009). Ekonomi dan pembiayaan pendidikan, Bandung: PT. Remaja Rosdakarya

[12] Nanang Fattah dan Sumarto, Policy Studies Of Educational Finance For
Teacher Education Indonesia, Proceeding of International Conference On Teacher Education, 2013 66-73

[13] Oluyele akinkugbe, Higher Education Financing, and Equality of Educational Opportunities in Swaziland, International Journal of Social Economics, 27, 2011, www.emerald-library.com

[14] Mark Olweny, Determining the Unit Cost of Higher Education: The Case of the Faculty of the Built Environment at Uganda Martyrs University, Journal Of Higher Education 36: 43-66, 1998

[15] Morey, Ann. (2001). The growth of for-profit higher education implications for teacher education. Journal of Teacher Education, hlm. 52 